MONIKA MUCHA

ORCID: 0000-0002-8525-0345

Uniwersytet Wrocławski

\title{
Moda — czynnik determinujący czy wykluczający udział seniorów w rynku?
}

DOl: 10.19195/2083-7763.9.9

\section{Wstęp}

Wszystkie kraje wysoko rozwinięte i te rozwijające się wykazują jedną, niemożliwą do cofnięcia tendencję - starzenie się społeczeństwa. Zwiększona liczba osób starszych w społeczeństwie ma wiele konsekwencji dla życia społecznego i gospodarczego. W wyniku mniejszej dzietności, wydłużania przeciętnej długości życia oraz narastającej liczby seniorów zmienia się struktura konsumpcji i jej poszczególnych dziedzin. Dotychczasowe stereotypy dotyczące osób starszych są nieaktualne. Seniorzy stają się ważnym segmentem konsumenckim. Ich wzrastająca świadomość przekłada się na aktywność życiową oraz związaną z tym konsumpcję mody.

Autorka na podstawie rozważań zarówno teoretycznych, jak i empirycznych danych wtórnych i pierwotnych szuka odpowiedzi na następujące pytania badawcze: Jakie jest miejsce mody we współczesnej konsumpcji? Czym dla seniorów jest moda? Jakie czynniki wpływają na sposób ubierania się seniorów? I wreszcie - Czy moda determinuje czy wyklucza seniorów z udziału w rynku?

\section{Miejsce mody we współczesnej konsumpcji}

Nie ulega wątpliwości, że współczesna konsumpcja przeobraziła się w mechanizm determinujący zachowanie i styl życia różnych społeczeństw. Ukierunkowanie gospodarki na masową produkcję w znacznym stopniu wpłynęło na życie społeczeństwa, które zaczęło utożsamiać się z tym, co oferuje rynek. W ciągu ostatnich kilkunastu lat powstało wiele dzieł i publikacji analizujących procesy konsumpcyjne 
i ich znaczenie w poszczególnych sferach życia człowieka. Najbardziej znani psychologowie czy socjologowie są zgodni, że konsumpcja zaczęła decydować o tym, kim jesteśmy, jaki mamy status społeczny oraz prestiż (Giddens 2009, s. 168-190).

Konsumpcja ma zarówno pozytywne, jak i negatywne strony, gdyż postrzegana jest jako proces $z$ jednej strony angażujący różne obszary i jednostki do działania, stanowiąc pewien ciąg zdarzeń, z drugiej zaś ustanawia reguły i zasady, które nie dla wszystkich są jasne i oczywiste.

Pod względem socjologicznym konsumpcja się rozwinęła, przez co obecnie mamy do czynienia nie tylko ze społeczeństwem konsumpcyjnym, mającym wiele specyficznych cech, lecz także z wieloma teoriami socjologicznymi i ruchami konsumpcyjnymi, które budują i poddają hierarchizacji struktury społeczne oraz oscylujące wokół nich nowe wartości. Jak podkreśla Alan Aldridge: „konsumpcja w naukach społecznych stała się pojęciem kluczowym” (Aldridge 2006, s. 9). Trudno przyjąć inne stanowisko. Konsumpcja jest obecna wszędzie - w codziennych czynnościach, jak jedzenie posiłków; jest także wyznacznikiem szeroko rozumianych aktywności społeczeństw (podejmowanie edukacji, pracy itp.). Szczegółowej analizy konsumpcji dokonał Łukasz Iwasiński, który w swoim dziele Socjologiczne dyskursy o konsumpcji przedstawia stworzone dotychczas „konstrukty" socjologiczne na temat konsumpcji. Autor udowadnia, że współczesny konsumpcjonizm jest „wyrazem życia społecznego, [...] wpływa na obowiązujące wzory zachowań (narzuca określone rozumienie konsumenta, stopnia jego racjonalności i wolności, przywilejów i obowiązków, funkcji i konsekwencji konsumpcji, oddziałuje na relacje, komunikacje z konsumentem, retorykę reklamy, itp". (Iwasiński 2016, s. 9). Co więcej, autor podkreśla, że współczesna konsumpcja powinna być wyznacznikiem znacznie szerszych działan - między innymi polityki konsumenckiej. Dlatego też nauki socjologiczne próbują wyjaśnić, w jaki sposób konsumpcja wpływa na życie społeczne, jak są formowane reguły i zasady postępowania oraz jakie są tego konsekwencje.

Nierozerwalnym zagadnieniem związanym z szeroko rozumianą konsumpcją jest moda. Jako samodzielne pojęcie jest trudne do jednoznacznego zdefiniowania, gdyż może być rozpatrywane zarówno w kontekście sposobu ubierania się, jak i sposobu kultywowania pewnych wartości. Jednym z autorów podkreślających niemożność zdefiniowania tego pojęcia jest François Boucher, który uważa, że „przypisując modzie wąskie znaczenie - bezustannych zmian podporządkowanych fantazji kreatorów oraz kaprysom użytkowników - zapomina się, zazwyczaj nieświadomie, o złożoności tej ewolucji, dającej się wytłumaczyć tylko ogromną różnorodnością kształtujących ją czynników" (Boucher 2003, s. 14). Jednak wchodząc głębiej w pojęcie mody, można dostrzec jej drugie oblicze funkcje, jaką pełni w społeczeństwie. Większość ludzi postrzega modę jako sposób ubioru — doboru spodni, koszul i ich kolorystki do własnego wyglądu. Ludzie podążają za modą — za tym, co oferują rynki modowe. W jednym sezonie modne 
są szerokie spodnie, pasiaste wzory, a w innym - stonowane, pastelowe kolory i dżinsy.

Moda się zmienia, przeobraża, przenika do życia codziennego. Podobnie jak współczesna konsumpcja, moda jest mechanizmem budującym tożsamość człowieka i wyznaczającym kierunek zachowania. Moda może być „na coś” lub „coś” może tworzyć modę, dlatego też powinna być ona traktowana jako boczna gałąź konsumpcji. Najwyraźniejszą egzemplifikacją są portale społecznościowe, zwłaszcza Instagram, gdzie ludzie - przeważnie młodzi - podkreślają swój ubiór, a przy tym tworzą własny wizerunek, stając się obiektem pożądania i poprawiając swoje samopoczucie. Popularyzacja sportu i zdrowego stylu życia odzwierciedla się w różnych strojach podkreślających bycie fit. Wykreowanie potrzeby prowadzenia zdrowego i sportowego trybu życia (choć jest bezwzględnie uzasadnionym działaniem z przyczyn biologicznych) wymusiło na wielu osobach określone zachowania i sposoby ubioru. W związku z masowym korzystaniem z portali społecznościowych moda doprowadziła do mocnego akcentowania tego, co ubieramy i przede wszystkim - jak ubieramy. Dzięki modzie jednostka wznosi się na pewien poziom. Zdaniem Adama Smitha sposób ubierania się nadaje człowiekowi określone cechy osobowości, podkreśla jego wejście w „wyższe sfery” (Smith 1989, s. 286). W odniesieniu do współczesności trudno się z tym nie zgodzić.

\section{Perspektywa i miejsce mody wśród osób starszych}

Moda jest pojęciem ulotnym i bezpośrednio odzwierciedlającym narzucone trendy. Poziom estetyzacji życia różni się w poszczególnych kręgach i grupach społecznych. Wydaje się, że grupą najbardziej oddaloną od mody są seniorzy, gdyż osoby starsze zwykle nie mają potrzeby bycia trendy. Ponadto, zakorzenione w mentalności społecznej myślenie, że seniorom „nie wypada” czegoś włożyć, hamuje potrzebę dotarcia do tej — jakże licznej - grupy społecznej.

Problematyka osób starszych jest coraz częściej podejmowana przez różne dyscypliny naukowe, w tym socjologię. Badacze i analitycy są zgodni, że społeczeństwa na świecie się starzeją, co oznacza, że w niedalekiej przyszłości społeczeństwa większości krajów będą stare lub starzejące się. Rzeczywistość, jaka otacza ludzi starszych, stawia przed nimi wiele wyzwań, z którymi muszą się zmierzyć. Jednym z nich jest rozwój technologii i dostęp do informacji, który zmienia podejmowanie decyzji w życiu codziennym. Jednak, jak potwierdzają w większości prowadzone badania w obszarze zachowań seniorów, znaczna część ludzi starszych jest odporna na nowości, innowacje, przez co niechętnie wykazuje nowe postawy, zgodne z obecnymi trendami (Olejniczak 2017, s. 129, 135).

Warto również podkreślić, że współcześni seniorzy są znacznie zróżnicowani względem siebie, co można zaobserwować w ich postawach, realizacji zadań czy podejmowanych decyzjach. Pomimo zakorzenionego systemu wartości 
i umiarkowanej otwartości na zmiany część seniorów z przychylnością utożsamia się z obecnymi zmianami. Seniorzy stają się obecni w coraz szerszych sferach społecznych, podejmują nowe praktyki społeczne, a także chętniej inwestują w siebie i własny rozwój, chcąc uniknąć szybszego zestarzenia się i popadnięcia w marazm (Rogala, Fojutowski 2014, s. 133).

Dyskusyjną kwestią staje się także granica wieku, od której rozpoczyna się starość. Współcześni sześćdziesięciopięciolatkowie, którzy niegdyś byli traktowani jako seniorzy, dziś są osobami aktywnymi zawodowo, uprawiającymi sport i kreatywnie spędzającymi czas wolny. Granica starości przesuwa się. Według amerykańskich antropologów kryterium starości jest przekroczenie 75. roku życia (Kaniewska-Sęba 2016, s. 145). Wpływ na określenie granic starości ma coraz szersza gama czynników determinujących wiek rozwoju, czyli: styl życia, poziom aktywności zawodowej, kondycja psychiczna. Pod uwagę bierze się również predyspozycje genetyczne wyznaczające wiek biologiczny jednostki oraz pełnienie ról społecznych określających z kolei wiek społeczny. Natomiast odbiega się od postrzegania starości przez pryzmat wieku chronologicznego, który w obecnych czasach przestaje być kategorią determinującą wyznaczanie starości (Wieczorkowska 2017, s. 79).

W modzie wiek nie zna granic. Współczesną modę wyznacza odmienność, szokowanie oraz wzbudzanie silnych emocji i kontrowersji. Osoby starsze mają określoną osobowość, nie mają zatem potrzeby poszukiwania nowych wzorów, aby stworzyć „projekt samego siebie”. Seniorzy z racji swojego wieku, doświadczenia i wiedzy przynależą do danej grupy społecznej, dzięki czemu nie mają potrzeby akcentowania swojego „ja” za pomocą ubioru i wyglądu (Leszniewski 2007, s. 52).

Panuje przekonanie, że osoby starsze nie prezentują we właściwy sposób modnych ubrań. Głównym powodem takiego myślenia jest ich pomarszczone i obwisłe ciało, które jest „brzydkie”, przez co modne ubrania nie wyglądają atrakcyjnie. Moda wywiera znaczny wpływ na młodych, nieukształtowanych osobowościowo ludzi. Daje im poczucie wyjątkowości i przynależności do elity. Tomasz Leszniewski zauważa, że moda i konsumpcja są podstawowym elementem budowania tożsamości, a dla wielu ludzi może „stanowić źródło rozkoszy i przyjemności" (Leszniewski 2007, s. 54). Jednak osoby starsze nie potrzebują kreować siebie i podążać za tym, co modne, a swoje potrzeby zaspokajają w inny sposób.

We współczesnej literaturze przedmiotu brakuje zarówno teoretycznych rozważań, jak i badań empirycznych, zwłaszcza w polskim piśmiennictwie, dotyczących roli i znaczenia mody w życiu osób starszych. Wydaje się zatem, że jest to nie do końca zbadana dziedzina, która wymaga pogłębienia i dokładnego wyjaśnienia naukowego. W krajach rozwiniętych (między innymi w Niemczech i Stanach Zjednoczonych) osoby starsze zupełnie inaczej postrzegają i odbierają modę niż w krajach rozwijających się (między innymi w Polsce, na Węgrzech i Ukrainie). 
W krajach zachodnich wiedza społeczeństwa jest bardziej rozwinięta. Bez względu na wiek ludzie są świadomi własnego ciała, ale także wnętrza, są znacznie bardziej odważni w swoich wyborach. Na ulicy nikogo nie szokuje kobieta po 60 . roku życia, elegancko ubrana - w krótką spódnicę i buty na obcasie. W Polsce wciąż silne jest przekonanie, że im osoba starsza, tym na mniej może sobie pozwolić. Na skutek zwiększania się przeciętnej długości życia ludzie starsi stają się coraz bardziej świadomymi konsumentami, a zarazem odbiorcami mody, obalając stereotyp „babci o lasce”.

Moda - czynnik determinujący czy wykluczający aktywność seniorów na rynku w świetle badań empirycznych?

Dojrzałość i osoby starsze zaczynają być w modzie. Przedsiębiorstwa modowe zdały sobie sprawę, że seniorzy są grupą konsumentów o niezwykłym potencjale. Polskie społeczeństwo, bez względu na wiek i płeć, jest raczej pragmatyczne pod względem wyborów modowych. Na zlecenie portalu internetowego Allegro przeprowadzono w 2015 roku badania „Zainteresowanie modą i zakupy modowe Polaków" (Raport Polska Strojna 2015) . W badaniu wzięło udział 1561 osób korzystających z internetu oraz 1840 osób robiących zakupy na portalu Allegro. Badania wykazały, że największe zainteresowanie modą jest u osób powyżej 64. roku życia, zwłaszcza wśród kobiet. Jednak osoby starsze nie należą do grupy, która śledzi trendy modowe. Mężczyźni w wieku powyżej 55 lat są grupą z najniższym wskaźnikiem śledzenia modowych trendów. Dla ponad połowy badanych powyżej 64. roku życia codzienny wygląd jest bardzo ważny. Okazuje się jednak, że istnieje spora rozbieżność pomiędzy stylem preferowanym przez osoby starsze i osoby młodsze. Seniorzy stawiają przede wszystkim na ubiór klasyczny, stonowany, porządny i elegancki. Z badań wynika także, że seniorzy w $88 \%$ nie mają ulubionych kolorów, które wybierają do noszenia na co dzień. Jest to zatem najliczniejsza grupa, która tak naprawdę nie przywiązuje wagi do rodzaju i kolorystyki wyglądu, lecz stawia na jego praktyczność i funkcjonalność połączone z wygodą. Osoby starsze wyznają także najmniej stereotypów dotyczących wyglądu. Oznacza to, że nie zastanawiają się, co jest w złym tonie. Jednak wśród seniorów znacznie więcej mężczyzn niż kobiet potrafiło wskazać, że „założenie adidasów do garnituru” jest niestosowne (25\%). „Założenie trampków do sukienki” za nietrafne uznało tylko $8 \%$ badanych kobiet powyżej 64. roku życia.

Badania przeprowadzone przez Allegro pokazują, że choć praktyki modowe seniorów nadal odnoszą się do tradycyjnych i klasycznych form, to wzrasta zainteresowanie modą i tym, co jest „na czasie”. Nie dziwi również, że znacznie częściej modą interesują się kobiety. Pomimo bycia seniorem kobiety nadal mają potrzebę czuć się pewnie i atrakcyjnie, a ubiór w tym pomaga. Dojrzałe kobiety są świadome, że wygląd ma znaczenie w kontaktach społecznych, a ubiór jest wizytówką 
człowieka. Nadal jednak czynnikiem hamującym aktywność modową seniorek jest brak odwagi i pewności siebie. Starsze kobiety nie są również spontaniczne w swoich decyzjach, wobec czego znacznie trudniej im wybrać look zgodny z aktualnymi trendami.

Seniorzy nie należą także do osób, które znacznie inspirują się modą. Badanie Po co seniorom kultura? Badania kulturalnych aktywności osób starszych, przeprowadzone nieco wcześniej - w 2012 roku - przez zespół badawczy z Uniwersytetu im. Adama Mickiewicza w Poznaniu, wskazuje, że „część osób starszych postanawia na starość odsunąć się w cień życia, nie wyróżniać się, pozostać na uboczu głównego nurtu rzeczywistości, między innymi dlatego, $\dot{z}$ istnieje społecznie kreowany wizerunek seniora jako osoby wywarzonej i wyciszonej" (Raport 2012, s. 110). To by uzasadniało, dlaczego starsze kobiety pomimo zainteresowania modą nie chcą stać się jej aktywnymi uczestnikami. Seniorzy przybierają asekuracyjne postawy $\mathrm{w}$ obawie przed kompromitacją. Niektórzy $\mathrm{z}$ nich rezygnują $\mathrm{z}$ własnych marzeń i pragnień, ponieważ nie będą wpisywać się w społecznie wykreowany wizerunek osoby starszej, przez co narażone zostaną na krytykę i ośmieszenie w oczach innych. Badania z 2012 roku dowodzą jednak, że coraz większa liczba seniorów jest świadoma konieczności dbania o siebie swoje zdrowie czy wygląd. Promowana w ostatnich latach aktywność seniorów zaczyna wypierać podgląd, że seniorom „nie wypada czegoś robić”, a w przypadku mody pozwala wybrać nowoczesny, kolorowy strój.

Badania przeprowadzone zarówno przez Allegro, jak i zespółbadaczy z Poznania dowodzą, że powoli zmienia się świadomość seniorów odnośnie do mody. Osoby starsze przekonują się, że wiek nie jest barierą w sposobie ubierania się. Jedyną przeszkodą są zakorzenione w społeczeństwie etykiety dotyczące starości i starzenia się, które hamują aktywność modową seniorów. Wszelkie zmiany w mentalności powinny dokonywać się zatem wśród znacznie młodszych pokoleń. Akceptacja społeczna jest pierwszym krokiem do zmiany podejścia seniorów, którzy przestaną obawiać się swojego wyglądu i ciała. Zachowanie i postawy młodszych wpływają na odbieranie własnego ciała i atrakcyjności przez osoby starsze.

Warto również przytoczyć autorskie badania Emilii Kramkowskiej. Autorka w 2017 roku przebadała grupę 355 studentów za pomocą sondażu diagnostycznego w celu zebrania opinii na temat cielesności i atrakcyjności seniorów. Zgromadzony materiał badawczy pokazał, że wpływ na postrzeganie drugiej osoby ma przede wszystkim wygląd fizyczny, który należy „do jednych z ważniejszych składników statusu społecznego, podlegającego stałej ocenie ze strony innych osób" (Kramkowska 2017, s. 25). Wniosek ten jest potwierdzeniem, że dla osób starszych wygląd ma znaczenie, dlatego z jednej strony interesują się oni modą i dbają o siebie, $\mathrm{z}$ drugiej jednak są zbyt nieśmiali, aby założyć odważniejszy ubiór. Badani studenci zdają sobie również sprawę, że ciało wraz z wiekiem się starzeje i nie powinno być głównym wyznacznikiem decydującym o atrakcyjności osoby. Zdecydowanie bardziej atrakcyjny dla ankietowanych jest intelekt 
seniorów i ich mądrość życiowa niż wygląd. W opinii badanych problemem nie jest starzejące się ciało, lecz niedbanie o siebie w podeszłym wieku. Moda to nie tylko strój, lecz także jego prezencja. Badani studenci uważają, że udział seniorów w życiu społecznym, a tym samym ich większa aktywność na rynku, może być determinowana większą troską o swój wygląd, ciało i zdrowie, co poniekąd narzuca współczesność (Kramkowska 2017, s. 27).

Na potrzeby podejmowanej problematyki wykonano także pilotażowe badania własne. Za pomocą kwestionariusza wywiadu przeprowadzono bezpośrednie rozmowy z nielosowo wybranymi respondentami. Dobór próby wyniósł 15 osób. Celem badania było określenie wpływu mody na udział seniorów w rynku i ich aktywności społecznej. Mimo iż badanie nie jest reprezentatywne, stanowi cenne dopełnienie poruszanego $\mathrm{w}$ artykule problemu.

Zdecydowaną większość badanych stanowiły kobiety (73\%). Spośród wszystkich 5 osób znajdowało się w przedziale wiekowym 64-67 lat, pozostałe osoby były w wieku powyżej 70 lat. W przypadku mężczyzn (27\%) wszyscy respondenci mieścili się w przedziale wiekowym 68-72 lata. Większość osób miała wykształcenie średnie (60\%). Tylko 3 respondentów to osoby z wykształceniem wyższym (27\%). Pozostałe 2 osoby mają wykształcenie podstawowe (13\%).

$\mathrm{Z}$ przeprowadzonych wywiadów wynika, że większość badanych zwraca uwagę na to, w co się ubiera. Dla respondentów istotny jest schludny wygląd. Zwłaszcza kobiety przyznały, że starają się wyglądać atrakcyjnie, „czysto” oraz właściwie dobierać poszczególne elementy garderoby. Mimo starszego wieku wszystkie respondentki zdają sobie sprawę, że obecnie moda jest czynnikiem warunkującym zachowanie osób, tym bardziej młodych. Wśród mężczyzn zauważono znacznie mniejsze zwracanie uwagi na ubiór, przy czym każdy z seniorów przyznał, że strój powinien być stonowany i wygodny.

Badania pokazały również, że żaden $\mathrm{z}$ respondentów nie podąża za trendami modowymi. Nieinspirowanie się modą powoduje, że osoby starsze traktują ją powierzchownie, jako „wybryk” współczesności. Znaczna część respondentów jest zdania, że „za modę się płaci”, co wzbudza w nich drażliwość i oburzenie. Seniorzy nie znają się na markach odzieżowych, nie uczęszczają do sklepów w celu nabycia nowego ubrania. Zdecydowana większość badanych kobiet ubiera się w sklepach oferujących odzież z drugiej ręki (tak zwanych lumpeksach). Mężczyźni natomiast najczęściej sporadycznie kupują ubrania. Jeżeli już dokonują zakupów, to zwykle w dużych, sieciowych hipermarketach.

$\mathrm{Z}$ autorskich badań wynika, że moda w opinii seniorów wiąże się ze schludnym wyglądem. Seniorzy są świadomi, że sposób ubierania się jest odzwierciedleniem także ogólnego zachowania, jednak badanym brakuje odwagi i determinacji, aby ubierać się modnie.

Analiza zarówno badań wtórnych, jak i własnych pokazuje, że znacznie częściej modą interesują się kobiety. Choć mężczyźni zwracają uwagę na swój wygląd i ubiór, to jednak kobiety zdecydowanie częściej kładą nacisk na szczegółowe elementy 
garderoby. Kobiety mają również mniejszy dystans do swojego ciała, przez co jest im trudniej wybrać odważny i modny strój. Mężczyźni natomiast wybierają wygodę i swobodę, w pełni akceptując swoje ciało. Prowadzone badania pokazały także, że im starsze pokolenie, tym większa niechęć do mody. Seniorzy, którzy ukończyli 70. rok życia, znacznie częściej przypisywali modzie materialny charakter. Z kolei seniorzy po 64. roku życia (zwłaszcza kobiety) przywiązywali większą wagę do wyglądu, zdając sobie sprawę, że jest on istotnym elementem w życiu człowieka. Młodsi seniorzy są także bardziej świadomi swojego ciała, a ich aktywny tryb życia powoduje, że czują się młodo i nadal chcą wyglądać atrakcyjnie.

Przeprowadzone badania własne potwierdzają wnioski wysunięte z badań wtórnych. Seniorzy to grupa osób, która zdaje sobie sprawę, że moda i ubiór są ważną częścią życia społecznego, lecz nie przywiązują do swojego ubioru tak dużej wagi jak młodsze pokolenia. Wśród badanych można dostrzec zakorzenione stereotypy, dodatkowo utwierdzające osoby starsze, że nie wypada im ubierać się w pewne „rzeczy”. Z całą pewnością mentalność seniorów wyklucza ich czynny udział w życiu społecznym, jednak widać coraz większą ich świadomość na temat sposobu ubierania się, co w przyszłości może całkowicie odwrócić obecną tendencję i determinować udział seniorów w rynku.

\section{Podsumowanie}

Seniorzy są grupa osób o mocno zakorzenionych wartościach, odmiennych od współczesnego świata konsumpcji. Komercjalizacja życia spowodowała, że seniorzy nie analizują rzeczywistości pod kątem materialnym. Osoby starsze dorastały w innej rzeczywistości niż współczesne społeczeństwo, co powoduje wielką przepaść pokoleniową. Jednak narastająca liczba osób starszych w społeczeństwie skłania do pochylenia się nad tą grupą społeczną, która w świecie mody wydaje się najbardziej pomijaną grupą. Pomimo rosnącej świadomości modowej seniorzy są wciąż marginalizowani, przyjmując postawę całkowitego wycofania się z mody. Sprzyja temu także samotność i wykluczenie z życia społecznego seniorów oraz warunkowane kulturowo poglądy, zakładające, że w pewnym wieku nie wypada ubierać się modnie.

W Polsce wciąż podejmuje się zbyt mało inicjatyw aktywizujących seniorów do uczestnictwa w modzie. Analiza badań w artykule pokazuje, że część osób powyżej 64. roku życia czuje się wciąż młodo i chce aktywnie spędzać swój czas oraz korzystać z modowych trendów. Większość respondentów zna podstawowe trendy modowe. Z badań wynika, że to głównie kobiety interesują się modą, jednak w obawie przed komicznym wyglądem i brakiem akceptacji ze strony otoczenia wybierają wygodny, stonowany ubiór. Większość badanych, bez względu na wiek i płeć, jest zdania, że ubiór powinien być dopasowany, a każdy element garderoby powinien współgrać z pozostałymi. Znacznie mniejszą wagę do mody 
i aktualnych trendów przywiązują mężczyźni, jednak względem akceptacji swojego ciała radzą sobie lepiej od badanych kobiet. Różnice w podejściu do mody, a tym samym do własnego ubioru, widoczne są również pomiędzy starszymi a młodszymi seniorami. Starsi respondenci, po 70. roku życia, mają obojętny stosunek do wyglądu i stroju. W ich opinii ważniejsza jest wygoda niż wygląd. Natomiast seniorzy, którzy dopiero ukończyli 64. rok życia, wciąż czują się młodo, przez co starannie dobierają ubiór. Wszyscy badani są także świadomi, że każdy element garderoby powinien ze sobą współgrać.

Osoby starsze, które pomimo upływu czasu nadal przykładają dużą wagę do swojego wyglądu i zdrowia, są bardziej radosne i komunikatywne w relacjach $\mathrm{z}$ otoczeniem. Jak wynika z badań własnych autorki i analizy badań wtórnych, seniorzy dzielą się na dwie grupy społeczne. Pierwszą z nich tworzą jednostki, które pomimo starzenia się nadal starają się dbać o swój wygląd, ubierać schludnie i elegancko, przez co nie czują się wykluczone z życia społecznego i szeroko rozumianej konsumpcji. Natomiast drugą grupę tworzą osoby starsze, dla których wygląd i moda nie mają znaczenia. Są to osoby, które nie potrafią odnaleźć się w obecnych czasach, żyją według własnych wartości i doświadczeń. Ich starość jest znacznie trudniejsza, a relacje $\mathrm{z}$ otoczeniem nie są najlepsze. Jednak drugą grupę tworzy znacznie mniej osób, które nadal są w pewien sposób wykluczone przez modę ze swojej aktywności. Pozostają bierne, w cieniu innych, młodszych pokoleń. Niemniej jednak zmiany w świadomości seniorów na temat ich stanu zdrowia i wyglądu przekładają się na lepsze postrzeganie mody. Pozwala to wysunąć wniosek, że w przyszłości moda stanie się czynnikiem determinującym udział seniorów w rynku. Wpływ na to będzie miało również to, że osoby starsze będą stanowiły znaczną część społeczeństwa, do której będą kierowane oferty handlowe związane między innymi z modą.

Przeprowadzone badania pilotażowe oraz omówione badania wtórne nie wyczerpują $\mathrm{w}$ pełni zagadnień związanych $\mathrm{z}$ podejmowanym zjawiskiem mody wśród osób starszych. Nie ma mocnych i rzetelnych danych pokazujących, jaki wpływ wywiera moda na życie osób starszych oraz jaki jest ich udział w modzie. Wydaje się, że jest to nadal słabo rozpoznany obszar, który wymaga zagłębienia się w niego ze względu na aktualność. Zaprezentowane wyniki służą zachęceniu do poszerzenia wiedzy na temat zachowań seniorów w odniesieniu do ich wyglądu i sposobu ubierania się.

\section{Bibliografia}

Aldrige A. (2006), Konsumpcja, przeł. M. Żukowski, Warszawa.

Boucher F. (2003), Historia mody. Dzieje ubiorów od czasów prehistorycznych do końca XX wieku, przeł. P. Wrzosek, Warszawa.

Giddens A. (2009), Europa w epoce globalnej, przeł. M. Habura, M. Klimowicz, Warszawa.

Iwasiński Ł. (2016), Socjologiczne dyskursy o konsumpcji, Gdańsk. 
Kaniewska-Sęba A. (2016), Polscy seniorzy - wyzwanie dla marketingu w XXI wieku, „Środkowoeuropejskie Studia Polityczne", nr 4.

Kramkowska E. (2017), Ludzie młodzi o atrakcyjności (ciała) współczesnego seniora, „Gerontologia Polska”, nr 26.

Leszniewski T. (2007), Moda i tożsamość - dylematy współczesnego człowieka w świecie konsumpcji, [w:] Rozkoszna zaraza. O rzadach mody i kulturze konsumpcji, red. T. Szlendak, K. Pietrowicz, Wrocław.

Olejniczak T. (2017), Innowacyjność w zachowaniach konsumentów seniorów - wybrane aspekty, „Studia Ekonomiczne. Zeszyty Naukowe Uniwersytetu Ekonomicznego w Katowicach”, nr 328.

Raport Polska Strojna (2015), Zainteresowanie modą i zakupy modowe Polaków, Mobile Institute, https://prowly-uploads.s3.eu-west-1.amazonaws.com/uploads/landing_page_image/ image/18384/Polska_Strojna_Zainteresowanie_Moda_i_Zakupy_Modowe_Polakow_Listopad_2015.pdf.

Raport z badań (2012), Po co seniorom kultura? Badania kulturalnych aktywności osób starszych, Poznań.

Rogala A., Fojutowski Ł. (2014), Decyzje zakupowe osób starszych-kryteria wyboru i czynniki wpły$w u$, „Marketing i Rynek” nr 4.

Smith A. (1989), O wplywie zwyczaju i mody na uczucia moralne. Aprobata i dezaprobata, [w:] Teoria uczuć moralnych, red. A. Smith, Warszawa.

Wieczorkowska M. (2017), Role społeczne współczesnych polskich seniorów w świetle wyników badań, „Acta Universitatis Lodziensis. Folia Sociologica” nr 6.

\section{Fashion: A factor determining or excluding the participation of seniors on the market?}

\section{Summary}

Fashion is an inseparable element of contemporary human life. In general, clothing choices are determined by age, gender and material factors. In terms of age, however, these decisions differ significantly, which is especially evident among the elderly. In consumer choices older consumers are usually guided by rationality. Seniors are currently a specific group of consumers on the market. On the one hand, they are marginalized because of their age and earnings, but on the other hand, it is a social group that begins to dominate the market, which in the near future will become a group of target recipients, including clothing products. When discussing fashion, there are also important characteristics of consumers that influence the fact of whether a given person is an active participant on the market or is an individual excluded from it. The purpose of this article is to try to define fashion as a factor determining or excluding the participation of seniors in the market. The paper presents an analysis of secondary research and the results of pilot studies on the attitude of seniors in the context of fashion. 